Pesq. Vet. Bras. 30(1):63-66, janeiro 2010

\title{
Acute and chronic nervous signs in cattle associated with Phalaris angusta poisoning in Argentina ${ }^{1}$
}

\begin{abstract}
Germán Cantón ${ }^{2 *}$, Carlos Campero², Matías Villa ${ }^{3}$ and Ernesto Odriozola²
ABSTRACT.- Cantón G., Campero C., Villa M. \& Odriozola E. 2010. Acute and chronic nervous signs in cattle associated with Phalaris angusta poisoning in Argentina. Pesquisa Veterinária Brasileira 30(1):63-66. INTA EEA Balcarce, CC 276, (7620) Balcarce, Argentina. E-mail: gcanton@balcarce.inta.gov.ar

Phalaris angusta is a South American natural grass that produces poisoning in sheep and cattle in Argentina and Brazil. Phalaris spp. can produce unrelated forms of poisoning in ruminants, acute and chronic syndromes. The objective of this paper was to describe an outbreak of acute and chronic Phalaris nervous syndrome in 53 of 980 fattening steers and heifers in a farm of Buenos Aires province. On September of 2006 the animals developed nervous signs and died after 3-5 days. The herd was removed to a phalarisfree pasture. Three months later (on December) 15 new clinical cases developed in the herd. Necropsy performed in one affected calf showed neither grossly nor microscopic changes. Microscopically, there were no major alterations in tissues. Nervous signs had been described in some field cases where neither pigment deposition nor axonal degeneration could be detected. Clinical findings displayed by affected cattle after consumption of Phalaris angusta pastures resemble those observed by other authors in Phalaris staggers. This is the first report in Argentina where both syndromes were seen in the same herd.
\end{abstract}

INDEX TERMS: Phalaris angusta, cattle, Argentina, acute, chronic, syndromes.

RESUMO.- [Sinais nervosos agudos e crônicos em bovinos na Argentina associados à intoxicação por Phalaris angusta.] Phalaris angusta é uma gramínea originária da América do Sul, que causa intoxicação em ovinos e bovinos na Argentina e Brasil. A intoxicação pode ocasionar quadros nervosos agudos ou crônicos, independentes um do outro. O objetivo deste trabalho é descrever ambos os quadros (agudo e crônico) da intoxicação por Phalaris em um rebanho de 980 garrotes em engorda na província de Buenos Aires. Em setembro de 2006, 53 animais desenvolveram sinais nervosos e morreram após um curso clínico de 3-5 dias. O rebanho foi trocado para uma pastagem sem Phalaris. Em dezembro, alguns animais apresentaram diarréia, depressão e perda progressiva de peso. Quando eram forçados a se movimentar, os sinais progrediam para incoordenação dos

\footnotetext{
${ }^{1}$ Received on July 21, 2009.

Accepted for publication on August 29, 2009.

2 INTA EEA Balcarce, CC 276, (7620) Balcarce, Argentina. *Corresponding author: gcanton@balcarce.inta.gov.ar

${ }^{3}$ Residencia Interna en Salud Animal, INTA EEA Balcarce.
}

membros torácicos, impossibilidade de se manter em pé e decúbito lateral. Havia perda de peso e os animais morriam após um curso clínico de 5-7 dias. Não foram observadas lesões macroscópicas nem histológicas nos animais com as duas formas da doença. Os sinais clínicos observados são semelhantes aos observados em outros surtos de intoxicação aguda ou crônica por Phalaris angusta.

TERMOS DE INDEXAÇÃO: Phalaris angusta, bovinos, Argentina, intoxicação aguda e crônica por Phalaris.

\section{INTRODUCTION}

Phalaris angusta Nees ex Trin. is a South American grass that grows in Brazil, Uruguay and Argentina (Odriozola et al. 1991, Marzoca 1993, Gava et al. 1999, Sousa \& Irigoyen 1999). It can be present as a weed in crops or as a useful component of unimproved pastures (Marzoca 1993, Gava et al. 1999, Sousa \& Irigoyen 1999). Outbreaks of $P$. angusta poisoning in sheep and cattle have been reported in Argentina (del Potro et al. 1984, Odriozola et al. 1991) and Brazil (Gava et al. 1999, Sousa \& Irigoyen 1999) but 
the forms of poisoning encountered at the time of each outbreak were not clearly defined.

Phalaris spp. can produce four different forms of poisoning in ruminants. Two are unrelated, peracute "sudden death" syndromes. One of these is called the cardiac 'sudden death' (Bourke et al. 1988; 1990; 1992, Bourke 1994, Bourke et al. 2006) and the other is called polioencephalomalacia-like 'sudden death' (Bourke et al. 2003a,b, 2005, 2006). The pathogenesis of the former is unknown but that of the latter involves ammonia toxicity. The other two forms of phalaris poisoning are related central nervous locomotor disorders, known as 'staggers' syndromes, one of these is acute and the other is chronic (Hartley 1978, Bourke et al. 1987, 1990, 2003a, Bourke 1994, Edgard 1994). The pathogenesis of the two staggers syndromes involves an indole alkaloid toxicosis. With acute staggers, animals become affected after 10 or more days of phalaris ingestion and then generally recover after they have been moved off a toxic pasture. With chronic staggers, animals do not necessarily become affected until many weeks or months after they have been moved from a toxic pasture, and they never recover. Neither the cardiac form of phalaris sudden death, nor the chronic form of phalaris staggers, has been reported in South America. The acute form of staggers has been reported in both Argentina (del Potro et al. 1984, Odriozola et al. 1991) and Brazil (Gava et al. 1999, Sousa \& Irigoyen 1999) but it is also possible that some of the affected animals reported by Odriozola et al. (1991) in Argentina and Gava et al. (1999) in Brazil, that is the animals that were lethally affected after only several days grazing phalaris, were affected by the polioencephalomalacia-like form of poisoning. The majority of these cases involved animals that were not affected until after 1020 days of grazing and these were clearly cases of acute phalaris 'staggers'. The phalaris central nervous locomotor disorder or 'staggers' was recognized by these investigators and was confirmed by the demonstration of characteristic microscopic pigments in the motor neurons of brain tissue taken from affected animals.

The aim of this paper is to describe an outbreak of concomitant acute and chronic Phalaris nervous syndrome in fattening steers and heifers in a farm of Buenos Aires province.

\section{MATERIALS AND METHODS}

On April 2006, a herd of 980 weaned calves (male and female) arrived to a farm located at San Miguel del Monte, Buenos Aires province, and was grazing pastures. On September, the herd was moved to a paddock of unimproved pasture of Phalaris angusta. After a week and during one month, 53 animals developed nervous disorders. Tissues from one affected calf were submitted in neutral-buffered $10 \%$ formalin (Animal 1). The animals were removed to phalaris-free pasture where they did not develop nervous signs.

On December 2006, 15 new clinical cases developed in the herd. No phalaris pasture had been grazed since October. Clinical signs were recorded on 4 affected cattle and samples of blood and faeces were taken. Hematocrit, total protein and serum albumin concentration by colorimetric techniques were performed on blood samples. Strongyle faecal egg and coccidia oocysts counts were determined on faeces.

One affected calf (Animal 2) was necropsied after euthanasia. Tissues were fixed in neutral-buffered $10 \%$ formalin, routinely processed for paraffin embedment, and stained with hematoxylin and eosin.

\section{RESULTS}

History. During September 2006, 53/980 cattle developed acute stagger syndrome on a paddock of unimproved pasture of Phalaris angusta. After a week and during one month they showed nervous disorders, characterized initially by hyperexcitability, marked incoordination, recumbence, inability to stand, convulsions, and death in 3-5 days. The herd was removed to phalaris-free pasture and the animals did not develop nervous signs after grazing was ceased.

On December 2006, 15 new clinical cases developed in the herd. No phalaris pasture had been grazed since October. The clinical signs displayed by affected animals were dyspnea, dullness and progressive weight loss. When they were forced to exercise they progressed to thoracic limb incoordination, lateral recumbence and inability to stand. The clinical signs could be exacerbated by periods of forced exercise. Affected calves appeared conscious during this lapse and death occurred in 5-7 days.

Postmortem findings. Macroscopic lesions on Animal 1 and 2 were no relevant. In Animal 2 a trichobezoar of $4 \mathrm{~cm}$ diameter was observed in abomasum and lipid mobilization of perirenal, mesenteric and pericardiac fat tissues were noted.

Laboratory examination. Microscopically, there were neither major changes in tissues submitted from an affected animal in the acute outbreak (Animal 1), nor from Animal 2. Slight gliosis in the protuberance, slight glomerular and perivascular nephritis were observed in Animal 2.

Results of serum biochemical analysis performed in Animal 2 were unremarkable except for lowed serum albumin levels (mean 2.65g/100 ml; normal range 4-6g/ $100 \mathrm{ml}$ ). Fecal analysis ranged from 0 to 1640 strongyle eggs and from 0 to 33600 coccidia oocysts/g.

\section{DISCUSSION}

The clinical findings displayed by naturally affected cattle after a week of consumption of Phalaris angusta pastures closely resemble those observed by other authors in Phalaris staggers.

$P$. angusta was identified in other field cases of phalaris toxicosis in Argentina (Odriozola et al. 1991) and Brazil (Gava et al. 1999, Sousa \& Irigoyen 1999). During 2006 similar cases had been registered by the Diagnostic Service of INTA Balcarce in Buenos Aires province (unpublished information), but it was sporadically diagnosed as mentioned by Odriozola et al. (1991).

Cattle were moved to phalaris pastures when the dominant specie was $P$. angusta in vegetative stage, in 
early grown period and with a profuse development (30$60 \mathrm{~cm}$ ). This fact was seen in other disease episodes (RietCorrea 1993, Gava et al. 1999, Sousa \& Irigoyen 1999).

In the present case, the episode occurred during spring. Other authors describe outbreaks in the same season (Hartley 1978); however, autumn (Riet-Correa 1993), in winter (Riet-Correa 1993, Parton et al. 2001, Radostits et al. 2002) and late summer (Hartley 1978, Riet-Correa 1993) were also mentioned.

Cattle affected with acute Phalaris stagger displayed generalized tremors, hyperexcitability, marked incoordination, hypermetria, recumbence and inability to stand, tachypnea, ataxia and convulsions. Similar signs were observed in natural (Hartley 1978, del Potro et al. 1984, Odriozola et al. 1991, Riet-Correa 1993, Gava et al. 1999) and experimental outbreaks (Gava et al. 1999, Sousa \& Irigoyen 1999). Other signs were characterized as thoracic and pelvic limb paresis, sternal and lateral recumbence, disturbed equilibrium, muscular asynergy, twitching of the face, ears and tale, sometimes of the whole body, propioceptive deficit and bounding (del Potro et al. 1984, East \& Higgins 1988, Bourke et al. 1990, Marzoca 1993, Gava et al. 1999, Radostits et al. 2002). In other clinical cases animals moved on their knees, so they apparently being unable to straighten their forelimbs (Hartley 1978, del Potro et al. 1984). According to other authors when exercise was forced, the clinical signs could be exacerbated (Hartley 1978, del Potro et al. 1984, East \& Higgins 1988, Riet-Correa 1993, Gava et al. 1999, Sousa \& Irigoyen 1999, Radostits et al. 2002).

In the acute stagger episode $5.4 \%$ of cattle were affected. The morbidity varied between 5 and $50 \%$ (Hartley 1978, Riet-Correa 1993, Parton et al. 2001).

Macroscopically, pigmentation in central nervous system and kidney in spontaneous and experimental cases were observed (Hartley 1978, del Potro et al. 1984, East \& Higgins 1988, Odriozola et al. 1991, Riet-Correa 1993, Gava et al. 1999, Sousa \& Irigoyen 1999, Parton et al. 2001). Focal, well-demarcated, bilaterally symmetrical, greenish-grey (Hartley 1978, East \& Higgins 1988, Odriozola et al. 1991, Gava et al. 1999, Radostits et al. 2002) or greenish-blue areas (del Potro et al. 1984, Sousa \& Irigoyen 1999) were seen in the midbrain corresponding to the pontine, lateral geniculate, or red nuclei, within the medulla oblongata and throughout the length of the spinal cord in ventral grey matter horns (Hartley 1978, del Potro et al. 1984, East \& Higgins 1988, Gava et al. 1999, Parton et al. 2001, Radostits et al. 2002). In kidneys similar pigmented area was found between cortex and medulla (Odriozola et al. 1991). In Animal 1 and 2, no gross changes were observed.

Microscopically, this pigmentation was found in the cytoplasm of large neurons of spinal cord and midbrain of affected cattle and sheep (Hartley 1978, del Potro et al. 1984, Bourke et al. 1990, Odriozola et al. 1991, Sousa \& Irigoyen 1999). These pigments apparently accumulate in the neurons where the alkaloids act (Radostits et al. 2002) and they also can be found in macrophages in central nervous system and cerebrospinal fluid (East \& Higgins 1988, Riet-Correa 1993). Other authors suggest that these pigments accumulate in and eventually destroy the affected neurons in spinal cord, midbrain and the epithelium of renal tubules (Hartley 1978, del Potro et al. 1984). The extensive accumulation of pigment in mitochondria probably interferes with cell function, leading to secondary demyelination, found in the spinal cords of affected sheep (Parton et al. 2001). Some field cases with nervous signs have been described, in which neither pigment deposition nor axonal degeneration could be detected (Bourke et al. 1990, Sousa \& Irigoyen 1999), maybe because these signs are produced by a biochemistry or not structural change (Sousa \& Irigoyen 1999). Phalaris pigments have also been demonstrated in the cell bodies of a number of cranial nerves which are referable to the prehensile malfunction seen in the delayed onset in affected sheep (Bourke et al. 1990).

It also can be found focal gliosis with mild neuronal loss in the spinal cord segments. Degenerative lesion throughout the spinal cord was the other major change (East \& Higgins 1988). In the most severely affected areas, it consisted of widespread individual axonal sheath swelling, with axonal necrosis and demyelination (Hartley 1978, del Potro et al. 1984, East \& Higgins 1988). This demyelination was seen when cervical portion of spinal cord was stained with Luxol Fast Blue, Fox and Weil-Wigert techniques (del Potro et al. 1984). Sometimes macrophage and other mononuclear infiltration in perivascular spaces were observed (East \& Higgins 1988, Sousa \& Irigoyen 1999). These processes can be stimulated by the demyelination (Sousa \& Irigoyen 1999). In these cases such pathological changes were not observed.

Until December, no more affected cattle were observed after the herd was removed from phalaris pasture. Del Potro et al. (1984) reported that some animals died after they were removed. Meanwhile, other authors described that clinical signs disappeared progressively until the complete recovery 20-30 days after the animals were removed from the pasture (Hartley 1978, Gava et al. 1999). Gava et al. (1999) reported that one affected cattle showed clinical signs after a year of its removal from phalaris pasture, showing prehensile malfunction.

After a period of 45 days that cattle were removed from phalaris pasture (Hartley 1978), animals progressively developed clinical signs (weight loss and incoordination). These animals definitively died after a period of 5-7 days. This chronic stagger syndrome was reported in sheep and cattle after several weeks (until 2 months) they were removed from the phalaris pastures (Bourke et al. 1987, 1990, Riet-Correa 1993, Radostits et al. 2002). In some cases, healthy sheep of an affected flock (with locomotor disturbances), display clinical signs 3-9 months after the exposure to Phalaris spp. (del Potro et al. 1984, Bourke et al. 1987, Radostits et al. 2002).

Chronic stagger affected cattle did not show diarrheic episodes which can explain the weight loss. Animal 2 had 
high coccidia oocysts count in faeces but no related lesions were grossly observed when necropsy and histopathological examination were performed.

The clinical examination of affected cattle with chronic syndrome revealed a poor nutritional condition, without diarrhoea and dullness. When they were stimulated to exercise they showed different degrees of incoordination. The progressive weight loss observed in affected animals can explain the fatty changes and biochemical findings. Other authors found prehensile malfunction of tongue and lips which can explain the negative nutritional imbalance observed (Bourke 1994, Sousa \& Irigoyen 1999, Radostits et al. 2002).

Microscopically, no changes were observed in Animal 1 and 2, so we can discard any other pathological condition.

\section{CONCLUSION}

Phalaris nervous syndrome or 'phalaris stagger' had been diagnosed in South America (del Potro et al. 1984, Odriozola et al. 1991, Gava et al. 1999, Sousa \& Irigoyen 1999). This paper describes the first report on concomitant acute and chronic stagger syndromes of cattle consuming Phalaris angusta in Argentina. According to these findings, it is likely to observe this situation when ruminants show neurological disorders.

Acknowledgements.- To Dr. Chris Bourke from the Orange Agricultural Institute, New South Wales Department of Primary Industries, Australia, for his valuable collaboration.

\section{REFERENCES}

Bourke C.A. 1994. The clinico-toxicological differentiation of Phalaris spp. toxicity syndromes in ruminants, p.523-528. In: Colegate S.M. \& Dorling P.R. (Eds), Plant-Associated Toxins: Agricultural, phytochemical and ecological aspects. CAB International, Wallingford.

Bourke C.A. \& Carrigan M.J. 1992. Mechanisms underlying Phalaris aquatica "sudden death" syndrome in sheep. Aust. Vet. J. 69:165-167.

Bourke C.A., Carrigan M.J. \& Dixon R.J. 1988. Experimental evidence that tryptamine alkaloids do not cause Phalaris aquatica sudden death syndrome in sheep. Aust. Vet. J. 65:218-220.

Bourke C.A., Carrigan M.J. \& Dixon R.J. 1990. The pathogenesis of the nervous syndrome of Phalaris aquatica toxicity in sheep. Aust. Vet. J. 67:356-358

Bourke C.A., Carrigan M.J., Seaman J.T. \& Evers J.V. 1987. Delayed development of clinical signs in sheep affected by Phalaris aquatica staggers. Aust. Vet. J. 64:31.
Bourke C.A., Colegate S.M. \& Culvenor R.A. 2006. Evidence that Nmethyltyramine does note cause Phalaris aquatica-related sudden death in ruminants. Aust. Vet. J. 84:426-427.

Bourke C.A., Colegate S.M., Rendell D., Bunker E.C. \& Kuhn R.P. 2005. Peracute ammonia toxicity: A consideration in the pathogenesis of Phalaris aquatica 'Polioencephalomalacia-like sudden death' poisoning of sheep and cattle. Aust. Vet. J. 83:168-171.

Bourke C.A., Rendell D. \& Colegate S.M. 2003a. Clinical observations and differentiation of the peracute Phalaris aquatica poisoning syndrome in sheep known as 'Polioencephalomalacia-like sudden death'. Aust. Vet. J. 81:698-700.

Bourke C.A., Rendell D. \& Colegate S.M. 2003b. Efficacy of the prophylactic use of thiamine and pyridoxine in sheep during an outbreak of Phalaris aquatica 'Polioencephalomalacia-like sudden death' poisoning. Aust. Vet. J. 81:637-638.

del Potro D.H., Odriozola E.R., Odeón A. \& Larralde S. 1984. Intoxicación en ovinos con falaris. Vet. Arg. 8:763-766.

East N.E. \& Higgins R.J. 1988. Canary grass (Phalaris spp.) toxicosis in sheep in California. J. Am. Vet. Med. Assoc. 192:667-669.

Edgard J.A. 1994. Toxins in temperate grasses-implication and solutions. N. Z. J. Agric. Res. 37:341-347.

Gava A., Sousa R.S., de Deus M.S., Pilati C., Cristani J., Mori A. \& Neves D.S. 1999. Phalaris angusta (Gramineae) como causa de enfermidade neurológica em bovinos no Estado de Santa Catarina. Pesq. Vet. Bras. 19:35-38.

Hartley W.J. 1978. Chronic Phalaris poisoning or Phalaris staggers, p.391-393. In: Keeler R.F., Van Kampen K.R. \& James L.F. (Eds), Effects of poisonous plants on livestock. Proc. Joint United StatesAustralian Symposium on Poisonous Plants at Utah State University, Logan, Utah, June 19-24, 1977. Academic Press.

Marzoca A. 1993. Manual de Malezas. Editorial Hemisferio Sur, Pelotas, p.190.

Odriozola E., Campero C., López T., Marin R., Casaro G. \& Andrada M. 1991. Neuropathological effects and deaths of cattle and sheep in Argentina from Phalaris angusta. Vet. Hum. Toxicol. 33:465-467.

Parton K., Bruere A.N. \& Chambers J.P. 2001. Phalaris (Phalaris spp.), p.324-326. In: Ibid. (Eds), Veterinary Clinical Toxicology. $2^{\text {nd }}$ ed. Publication no 208. Foundation for Continuing Education of the New Zealand Veterinary Association and Veterinary Continuing Education. Massey University, New Zealand.

Radostits O.M., Gay C.C., Blood D.C. \& Hinchcliff K.W. 2002. Intoxicación por dimetiltriptamina y feniletilamina, p.1962-1964. In: Ibid. (Eds), Medicina Veterinaria, tratado de las enfermedades del ganado bovino, ovino, porcino, caprino y equino. Vol.2. McGraw-Hill-Interamericana de España, S.A.U.

Riet-Correa F. 1993. Intoxicação por Phalaris spp., p.132-136. In: RietCorrea F., Méndez M.C. \& Schild A.L. (Eds), Intoxicações por Plantas e Micotoxicoses em Animais Domésticos. Vol.1. Editorial Agropecuaria Hemisferio Sur SRL, Montevideo.

Sousa R.S. \& Irigoyen L.F. 1999. Intoxicação experimental por Phalaris angusta (Gramineae) em bovinos. Pesq. Vet. Bras. 19:116-122. 